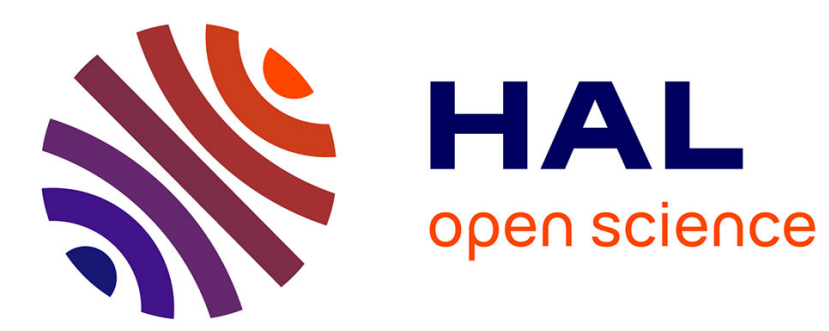

\title{
French Labor Tribunals and the making of Labor law. Toward a sociology of judiciary roles
}

\author{
Laurent Willemez
}

\section{To cite this version:}

Laurent Willemez. French Labor Tribunals and the making of Labor law. Toward a sociology of judiciary roles. Sociologie du Travail, 2013. halshs-02615644

\section{HAL Id: halshs-02615644 \\ https://shs.hal.science/halshs-02615644}

Submitted on 25 May 2020

HAL is a multi-disciplinary open access archive for the deposit and dissemination of scientific research documents, whether they are published or not. The documents may come from teaching and research institutions in France or abroad, or from public or private research centers.
L'archive ouverte pluridisciplinaire HAL, est destinée au dépôt et à la diffusion de documents scientifiques de niveau recherche, publiés ou non, émanant des établissements d'enseignement et de recherche français ou étrangers, des laboratoires publics ou privés. 

Not for reproduction, distribution or commercial use.

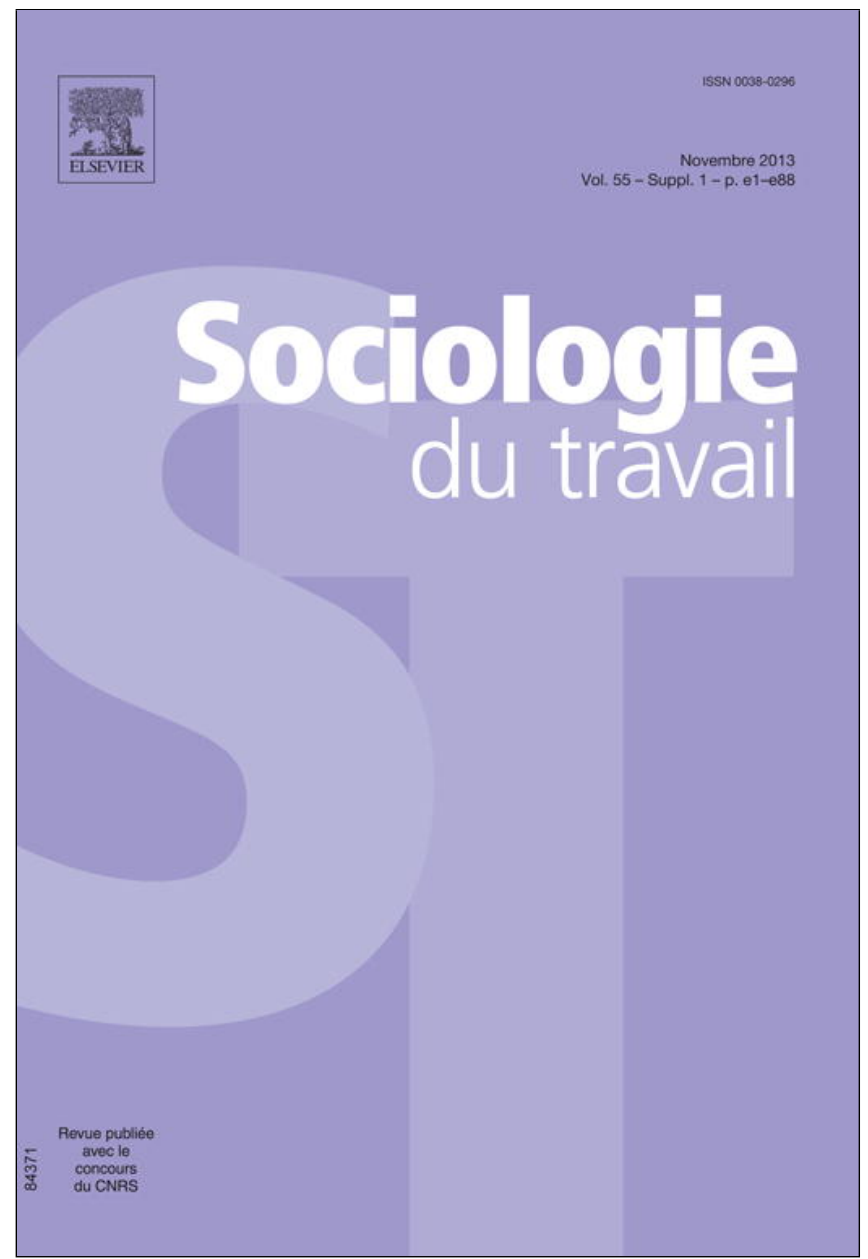

This article appeared in a journal published by Elsevier. The attached copy is furnished to the author for internal non-commercial research and education use, including for instruction at the authors institution and sharing with colleagues.

Other uses, including reproduction and distribution, or selling or licensing copies, or posting to personal, institutional or third party websites are prohibited.

In most cases authors are permitted to post their version of the article (e.g. in Word or Tex form) to their personal website or institutional repository. Authors requiring further information regarding Elsevier's archiving and manuscript policies are encouraged to visit:

http://www.elsevier.com/authorsrights 


\title{
French Labor Tribunals and the making of Labor law. Toward a sociology of judiciary roles ${ }^{\text {tr }}$
}

\author{
Laurent Willemez \\ Department of sociology, University of Poitiers, 8, rue René-Descartes, 86022 Poitiers cedex, France \\ Available online 11 November 2013
}

\begin{abstract}
How do the verdicts of French joint industrial tribunals (Conseils de prud'hommes) participate in shaping the law in the field of labor relations? A "sociographic" survey brings to light both the multiplicity of forms of commitment to the institution and the key role played by a group of "professionals" in these labor tribunals, where elected representatives of employer associations and trade-unions sit side by side. Analyzing how councillors are socialized by the institution and how they arrive at their decisions shows that judgments stem from a combination of three different rationales: the law, union representation and the world of work. Between magistrates' social characteristics, institutional affiliations and manners of judging, a new way of studying judiciary activity is suggested.
\end{abstract}

(C) 2013 Published by Elsevier Masson SAS.

Sociological research on law and justice runs into difficulties when it must analyze all at once the men and women who daily produce and apply legal categories and the results of their activity, i.e. laws as they are created and implemented. Calling upon a sociology of social institutions on the other hand allows us to grasp how the actors of a legal institution fill their position, produce legal categories and make laws. Of all jurisdictions, joint French labor tribunals (Conseils de prud'hommes) — where representatives of employer associations and trade-unions sit side by side - are the most appropriate arena in which to work on questions that combine personal involvement in judicial roles and the manufacture of a judicial system.

Such a tribunal seems the perfect example of a law-making institution. First, because personal investment in their role as councillors (prud'hommes) brings many different identities into play. French Prud'homme councillors are at the crossroads of several fields, whose underlying logics are nearly always presented as antithetical. They are above all else magistrates who apply the

\footnotetext{
is Translation: Gabrielle Varro.

E-mail address: Laurent.willemez@univ-poitiers.fr
} 
law — under the watchful eye of various legal professionals and the appellate courts, always prompt to challenge the validity of their decisions. But their legitimate nature also depends on a second attribute: they represent trade-unions or employers' associations and are good connaisseurs of the realities of the working world. Each councillor belongs to a college - employer or employee - is member of a union, and a participant in the world of labor with its own rules and regulations ${ }^{1}$, i.e. a three-pronged identity that confers a true "grassroots competence" (Michel, 2008).

As a result of countless interactions, negotiations and power struggles, the laws created by prud'homme councillors are destined to become judicial categories and eventually general law by virtue of jurisprudence. Yet, when analyzing the activity of the institution, the categories it produces are in fact the consequence of actors' efforts to define a truth capable of satisfying the bench, and at the same time living up to trade-union expectations and the realities of the working world. That is why analyzing labor tribunals gives us insight into the modus operandi of the law rather than into the law as an opus operatum. Exploring the sociology of the councillors themselves as well as their ways of arriving at decisions, and the systems that organize the institution by which and for which they sit in judgment, also means investigating the contents and specific nature of the laws they produce.

To study how councillors become part of the institution, construct their role as prud'hommes and produce laws, we take a second look at part of the results obtained in a survey on labor tribunals carried out with Hélène Michel and a team of sociologists and political scientists in 2006 and 2007. Contrary to the relatively sparse material that exists on the subject — that more often than not focuses on a single monography - we chose to apply two research methods simultaneously: on the one hand, a survey by questionnaire sent to a sample of nearly 3000 councillors (with a return of 800$)^{2}$, and on the other hand, a qualitative survey mixing observation and about one hundred interviews carried out in ten prud'homme tribunals throughout France ${ }^{3}$. A sociographic analysis of the councillors themselves exposes the processes whereby labor laws are produced.

\section{From parity to the force of experience: modes of prud'homme commitment and diversity in the conceptions of labor law}

The divisions classically invoked when analyzing prud'homme councillors are doubtless too coolly objective to account for the sociological realities of the institution which, if truth be told, councillors also contribute to mask. The questionnaire, and processing the results thanks to a factorial correspondence analysis, are precisely intended to elucidate those other, less obvious sorts of differences among them.

\footnotetext{
1 The specifics of each professional activity are reflected in the fact that a Labor Tribunal is organized in five sections (industry, commerce, agriculture, management, miscellaneous activities), which is also the framework for organizing elections and sharing out cases.

${ }^{2} N=806 ; 393$ are employees and 413 are employers, the sample thus corresponds — in a way that might be considered significant - to the principle of parity, one of the institution's fundamental structures.

${ }^{3}$ For an exhaustive presentation of results see Michel \& Willemez (2007).
} 


\section{Factorial analysis method}

The factorial correspondence analysis (FCA) applied here was based on a self-administered, postal questionnaire sent to nearly 3000 councillors, of which 806 were filled out and returned. The response rate $(26.8 \%)$ is all the more remarkable as the questionnaire contained over 100 questions bearing on respondents' practices, representations of the institution, activities as prud'homme councillors, and social and economic backgrounds. Coded and treated by a team directed by Diane Delacourt and Florence Gallemand, research engineers at CURAPP (CNRS-University of Picardie Jules-Verne), the results were then fed into the program "Modalisa".

Of the 100 questions, 17 active variables (corresponding to 60 modalities) were used for the FCA, and 7 others were added at different times during the processing. Re-coding allowed preserving a certain uniformity in the number of modalities for each question, though it was not always possible to create groupings, in particular given the variety of organizations to which councillors belong.

Active variables describe their prud'homme activities: the date they entered the institution, the section, union or professional association that elected them (not forgetting that many employer-councillors prefer declaring they belong to no organization); whether they are president or vice-president of a tribunal or a section; their participation in interim hearings - in some urgent situations, the tribunal may meet for an interim hearing with two members only vs. four in the final hearings, to decide on provisional measures e.g. reinstating an employee, paying a salary, submitting documents, etc. - and their more farreaching judiciary activities, such as following up a training program; role as trainer; working in a legal department; participating in other joint jurisdictions or jurisdictions partly made up of non-professional judges (Social Security tribunals, juvenile courts, local magistrates, etc).

There are also morphological variables: gender, profession and socioprofessional category (SPC), occupational status ${ }^{4}$, level of diploma. It seemed indispensable to study the population of councillors as a whole, therefore we needed to eliminate variables that did not concern the entire group, whence the paucity of trade-union variables, of which only one was retained: the number of responsibilities held within an organization (baptized "mandate" in the FCA). Linking up the other questions implied pooling variables that had totally different meanings for employers and employees (e.g. union mandates as delegates of personnel in a firm and mandates as representatives of employer associations in joint jurisdictions: Unedic [National Union for Employment in Industry and Commerce], Social Security, vocational training, etc. $)^{5}$.

\footnotetext{
${ }^{4}$ This is naturally the most important question concerning employers. The breakdown is as follows: retired employer, self-employed or liberal profession, salaried employer.

5 On the very complex question of "mandates", $c f$. Offerlé (2009) (p. 91).
} 
Extra variables pertained to what entering the institution meant to them (reasons for wanting to run for office, previous familiarity with the prud'hommes), as well as to their social relations within the tribunal (perception of how councillors get along and how tasks are shared out) ${ }^{6}$, and to legal aspects (collaborating to draft an opinion, putting questions to lawyers and what councillors look for in a file to help them form an opinion).

\section{1. "Professional prud'homme" employees and small company directors}

The first axis of the FCA (Fig. 1) represents the gulf separating employers from employees, an opposition that, given the parity rule underlying the prud'homme tribunal, lends it its main meaning. Even when the "college" variable is eliminated (because overly significant) a whole series of variables and modalities - union or employer organization, professional status or, though to a lesser extent, type of diploma - recall and emphasize the contrast between them. Parity, which structures the French Conseil de prud'hommes institutionally — all decision-making is done jointly and members of both colleges alternate in the influential positions - also divides the population sociologically (Table 1). Overall, the employer college is somewhat less feminized than the employee college ${ }^{7}$, and socio-professional level is largely superior in the former, because a large number of employer councillors are themselves CEOs — particularly human resources managers - or members of the higher intellectual professions. Employer prud'homme councillors are also frequently directors or top executives in companies with small numbers of employees: over half of the employer-councillors work in companies of fewer than fifty employees. Among employer associations union divisions often disappear under the pressure to achieve parity. Employer-councillors are also far more qualified, and the labor law they defend is more academic — but also more geared towards personnel management.

At the other extreme, many employee-councillors are employed by large firms, are less qualified professionally and have several responsibilities within their labor organizations (whereas employer-councillors have very few mandates). But it is clear from the graph that the parityinduced opposition also refers to a functional division within the tribunal itself: directing the Prud'hommes, occupying influential posts and various legal positions more or less directly connected to it are functions in the majority shouldered by employees. We see that all the positions of tribunal or section president or vice-president, interim relief judge, instructor or member of a legal department crowd into the right hand side of the graph, not the left. Were we to calculate a "score" of prud'hommes responsibility in the tribunal, employees clearly dominate (cf. Table 2). The low level of participation of employer associations can be variously explained by lack of time for those activities, or differences in remunerations between employer and employee councillors ${ }^{8}$.

\footnotetext{
${ }^{6}$ When prud'homme councillors sitting on the same committee cannot agree on a unanimous verdict, the Labor Code ("Code du travail") stipulates they must appeal to a judge in a lower court (Tribunal d'Instance).

7 All in all, over $78 \%$ of the sample is male, as in the IRES survey of 2002 which, on this point, was quite exhaustive (Dufour \& Hege, 2002). It should be noted that in 2006 a law made parity mandatory on the tickets for prud'homme elections.

8 The problem of indemnifying prud'homme councillors is complex: though employees are paid when at the tribunal during their working time (the State reimburses their employer for the salaries paid out), retired employees or employers are only paid a modest hourly wage ( 7 to 14 euros/hour). A rationalization of those indemnities was implemented in the
} 


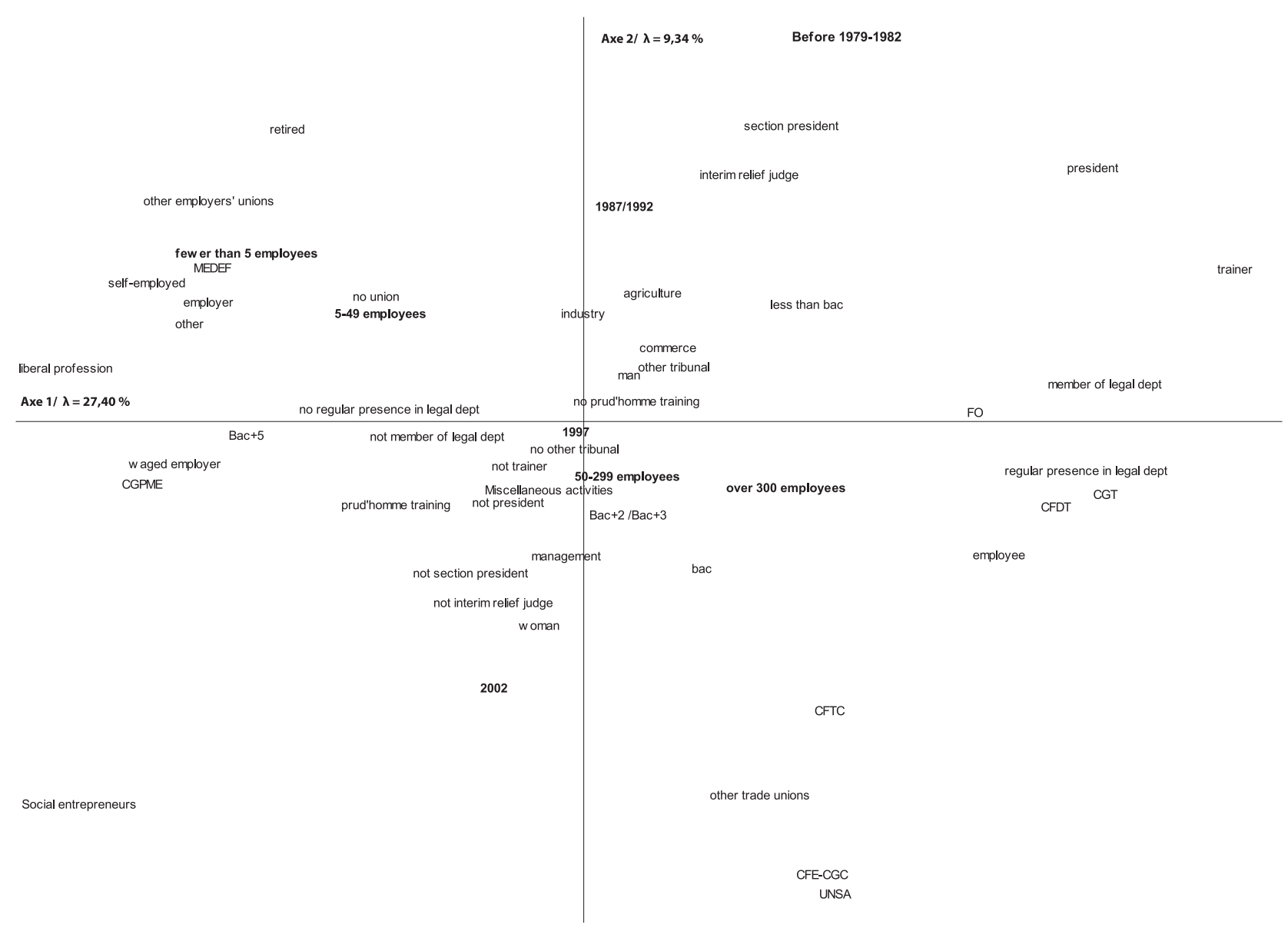

Fig. 1. Factorial correspondence analysis, axis $1 /$ axis 2 .

Official parity is thus seriously challenged by the reality of disparity in an institution in fact directed by employee councillors. A first pole is formed by those we might call "prud'homme professionals", often also professionals of legal trade-unionism. A certain number of characteristics set them apart: they are affiliated to the trade-unions who actually run the institution (the CGT, Confédération générale du travail, General Workers' Confederation; the CFDT, Confédération française démocratique du travail, Democratic French Labor Confederation; and, somewhat more modestly, FO, Force ouvrière), they fill many positions in their unions, tend to come from the world of intermediary occupations or employees (less often blue-collar) and often are not very endowed educationally. Among councillors presently holding or who have held three mandates, $43.1 \%$ never finished secondary school, i.e. do not possess a Baccalauréat, as against $60 \%$ of councillors with $\mathrm{Bac}+5$ years of higher education who do not have any particular responsibility and if we consider only employees, $68 \%$ of those who have Bac +5 also do not fill any responsible position. But many have had training connected to the prud'hommes and labor law. That means that to a large extent the prud'hommes council remains a typical working-class "school", where lower and middle-class union activists are acculturated ${ }^{9}$. At the same time, these councillors play an important part in the legal work of their union (particularly as members of its legal department

Desclaux report (October 2005) and by decree in June 2008 (which decomposed each activity and indicated the amount of time to be spent on it), but was cancelled by the French Conseil d'État in March 2010.

9 Prud'homme councillors resemble their trade-union peers who have responsibilities in their union; the case of the CFDT studied by Guillaume and Pochic (2009) (p. 53) seems to be an exception. 
Table 1

Prud'homme councillors' main morphological variables.

\begin{tabular}{lcc}
\hline & Employer $(\%)$ & Employee $(\%)$ \\
\hline Gender & & 76.2 \\
Male & 80.4 & 23.7 \\
Female & 19.6 & 41.3 \\
Diploma & & 17.2 \\
CEP-CAP-BEP & 23.2 & 33.8 \\
Baccalauréat & 10.4 & 7.8 \\
Bac + 2, Bac +3 & 26.4 & \\
Bac +5 & 40.0 & 2.1 \\
Size of firm & & 9.7 \\
Fewer than 5 employees & 18.6 & 19.7 \\
Between 5 and 49 employees & 32.2 & 68.4 \\
Between 50 and 299 employees & 18.4 & \\
Over 300 employees & 30.7 & 0.3 \\
SPC & & 26.1 \\
Company head, liberal profession & 40.6 & 32.5 \\
CEO and upper intellectual professions & 46.5 & -
\end{tabular}

$N=806$ (employers = 413; employees $=393$ ); no-answers excluded; SPC: socio-professional categories.

Table 2

Councillors' responsibilities according to college.

\begin{tabular}{lcccc}
\hline & \multicolumn{2}{l}{ Employer } & & \multicolumn{2}{c}{ Employee } \\
\cline { 2 - 3 } & $N$ & $\%$ & & $N$ \\
\hline None & 234 & 58.2 & 168 & 41.8 \\
1 mandate & 99 & 48.5 & 105 & 51.5 \\
2 mandates & 65 & 41.9 & 90 & 58.1 \\
3 mandates & 15 & 15 & 30 & 66.7 \\
Total & 413 & 413 & 393 & 48.8 \\
\hline
\end{tabular}

$\mathrm{Khi}^{2}=19.6 ; \mathrm{ddl}=3 ; P=0.001$.

and as instructors). Some of them also serve as permanent or semi-permanent officials, putting in countless hours as union delegates, specializing in legal advice and defending their co-unionmembers ${ }^{10}$. The judicial resources thus brought into play are very specific and the outcome is a very practical sort of law, which explains why these councillors see themselves above all as mediators between wage-earners and the law.

When the size of the firm which councillors belong to or direct is taken into consideration, however, the "employer councillors" category splinters: over $40 \%$ of them are small entrepreneurs, SME (Small and Medium-Sized Enterprises) officials with a very individualistic conception of social relations; often they have come to the prud'hommes because they lived through a painful

\footnotetext{
${ }^{10}$ We know that since the start of the $20^{\text {th }}$ century prud'homme councillors have been the "backbone" of legal trade unionism (Willemez, 2003).
} 
Table 3

Distinctive functions in the labor tribunal according to year of arrival.

\begin{tabular}{|c|c|c|c|c|c|}
\hline & 1979/1982(\%) & $1987 / 1992(\%)$ & $1997(\%)$ & $2002(\%)$ & Total $(\%)$ \\
\hline President/vice-president of tribunal & 39.1 & 17.7 & 11.0 & 6.7 & 14.5 \\
\hline President/vice-presidentof a section & 71.7 & 52.0 & 33.3 & 13.3 & 35.3 \\
\hline Interim relief judge & 64.4 & 57.1 & 37.7 & 21.5 & 39.8 \\
\hline
\end{tabular}

$N=806 ; \mathrm{Chi}^{2}$ results very significant for all data.

litigation themselves. The factorial analysis of the employer councillors category explicitly opposes two groups: on one side, councillors who are professional employers or self-employed, control small or very small firms and have a relatively low level of education and, on the other side, councillors from large firms, CEOs or retired, with high levels of education. These small business leaders make up a very identifiable sub-group among employer councillors. The labor law they stand for is oriented towards inter-individual arrangements and conciliation rather than institutionalized and officialized conflicts such as court hearings are made of. In that, their attitude in the labor tribunal corresponds to the ethos they stand for in their firms as well as in their social life generally (Zarca, 1986).

\subsection{The experience of judging}

Though parity is truly the main dividing line in the prud'homme institution, observing the second axis of the FCA permits highlighting another sort of opposition: the contrast between experienced councillors and newcomers. In fact, the vertical axis seems quite systematically organized, with the least senior councillors (elected in 2002) at the bottom of the graph and the most senior councillors (elected in 1979 or earlier) at the top. Other variables compound the opposition: for instance, associations that entered a prud'hommes tribunal recently (in particular the Union nationale des syndicats autonomes, UNSA, and employers of the social economy) are at the very bottom of the graph. Similarly, while retired employers are at the top, salaried employers are at the bottom, which shows up the morphological transformation of the group of employers, with the number of pensioners regularly dropping and the number of wage-earners progressively rising (36.1\% of all employers, and $47 \%$ of those elected in 2002). The strength of seniority also correlates with the most prominent positions, very largely assigned to the most senior councillors, i.e. those with the most experience (cf. Table 3).

This last point is not at all a foregone conclusion, in the sense that leadership in the institution could very conceivably depend on other resources, such as the level of education and diplomas. It is therefore really a form of "specific capital" (Mauger, 2006) that structures part of the institution's organization, a "specific capital" that includes knowledge of how prud'homme councils function, knowledge about how to handle legal tools and categories, and experience in representing principals. Thus, were the modalities of what is being sought after in the files during deliberations projected as an extra variable, "jurisprudence" and "collective agreement" would appear at the top of the graph, and employee's or employer's "demands", or "facts presented" by the one or the other, at the bottom. Being in the shoes of a prud'homme councillor implies taking into account the most legal, institutionalized and formal ways of administering justice as well as keeping what is most accessible and least formal at a distance. In these representations of what it means to be a prud'homme, the double bind of needing to respect both judicial conformity and union representation is perceptible. 


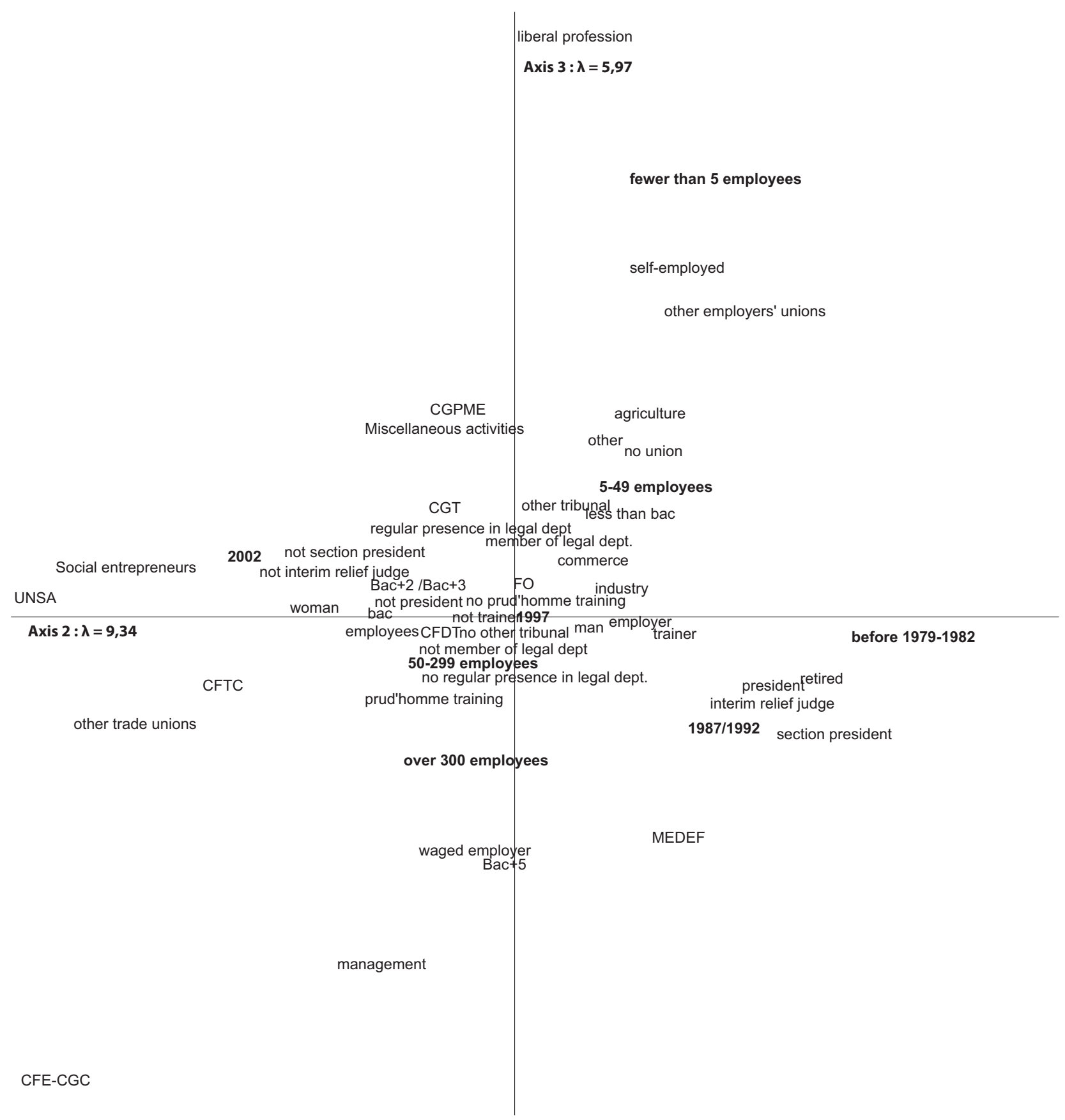

Fig. 2. Factorial correspondence analysis, axis 2 / axis 3.

The impact of this axis is even more obvious when the central divide - the backbone of the institution - is neutralized, i.e. when an FCA is carried out for each college separately. The two graphs are organized in approximately the same manner, the main axis opposing councillors with and councillors without experience. The FCA done on employee councillors confirms the presence of a very experienced group of councillors in eminent positions, compounding roles of legal trade-union representation, training, manning the office and other union tasks as well.

But, as the analysis of axis 3 demonstrates, prud'homme professionals present two quite different profiles. Totaling $5.97 \%$ of the inertia, the axis underlines the significance of the diploma and of the social-professional category (Fig. 2); it shows that employers with few social and educational qualifications, who belong to the Employers' Union (Confédération générale du 
patronat des petites et moyennes entreprises, CGPME), resemble their employee counterparts in the CGT labor union (in FO to a lesser extent). The FCA also allows grasping the social proximity - usually hidden behind college rivalry - between executive employees, whether or not they belong to the Executive Trade-Union (Confédération générale des cadres, CGC), and salaried employers. This last category is not the oxymoron it might appear to be, since over one-third of employer-councillors are in executive positions in their firms, often in charge of human resources or as directors. Training the spotlight on this axis also reveals the specificity of the tribunal's management section, where men and women, whose statutory positions resemble those of the peers they are there to judge, do so in a perspective that seems particularly corporatist (in the historic sense of the word). They are perhaps the only councillors for whom the border between colleges seems particularly porous. At the end of the day, "managerial" councillors defend a law that is, if not "pure", at the very least much more academic, and they readily supplement their activity as prud'hommes by writing articles on jurisprudence. Being in a vastly more dominant position with regard to the law, they also accuse a greater distance from judicial obligations, and astutely play the legal game, which is a game with forms, tools and categories.

André B. is a perfect example. A specialist of labor law at the prud'hommes, 75 years of age at the time of the interview, councillor in the management section of a large tribunal since 1987, he was previously HR director in a large French industrial group that belongs to "Entreprise et progrès", an employers' think-tank, and associate professor of labor law in a school of higher education. Very active in his section at the time of the interview, he pointedly and proudly talks about "beautiful" decisions, with an outlook very comparable to that which is typical of law professionals: "I like to write, it amuses me. I take my time because I check everything. I have a wealth of documentation and there are points I'm especially interested in on which I've written a paper [...] It's an opportunity to check if the reasoning was correct". (Interview 26 April 2006).

A certain number of councillors have incorporated a bonafide prud'homme habitus, marked by the fact they share what Pierre Bourdieu called a "world of common sense", a "consensus on the meaning of practices and of the world" of labor law - or even of the world of labor per $s e$ - as being the product of a form "of harmonizing experiences" 11 thanks to the time spent in prud'homme activities, but also due to the rituals and symbolic gratifications dispensed by the institution. This would explain that, despite the existence of the aforementioned group of highly qualified councillors, a premium is granted to seniority and experience rather than to diplomas or the more classical, formal resources. These councillors convey a particular form of law, that depends less on the academic, jurisprudential or doctrinal categories than on actual practice. As Christian Bessy put it, theirs is a "law centered on practice, on the outlook for solutions that suppose that a form of collective apprenticeship takes place between the parties involved" (Bessy, 2007 , p. 236), or yet again - and to apply the categories of the sociology of economics and compare them to the magistrates of business tribunals - ${ }^{12}$ what Emmanuel Lazega has called the "experience-based pragmatism" of judges, for whom decisions "come from adding knowledge of economics and management to the knowledge of law and jurisprudence". These councillors produce "their own synthesis of law, management and economics, but count on the routines of the

\footnotetext{
11 Original French text: “...marqué pour ces acteurs par la constitution entre ceux-ci d'un «monde de sens commun », d'un «consensus sur le sens des pratiques et du monde» du droit du travail (et peut-être même du monde du travail), produit d'une forme «d'harmonisation des expériences » (Bourdieu, 1980, p. 97)".

12 Judges in the business tribunals are also non-professional.
} 
business world, common good sense and equity" (Lazega, 2009, p. 103). They promote a labor law that is practical rather than theoretical, nourished more by the articles of the Labor code than by jurisprudence, and based on the description of work relations by each party rather than on lawyers' pleas.

The example of Frédéric J. is illustrative of prud'homme professionals who produce that sort of practical rather than scholarly law: as employee-councillor (CGT) in the Industry section of a prud'homme council in an industrial town since 1997, himself a metal worker aged $c a .40$ at the time of the interview, he was a certified mechanic and electrician thanks to a Certificat d'aptitude professionnelle (CAP) and Brevet d'études professionnelles (BEP) in each specialty. He has been working for many years in a foundary, where he cumulated a whole collection of representative mandates, putting in many hours as delegate. Ferociously opposed to school ("Studying gives me the creeps. In my opinion, schools produce idiots [...], higher education is a waste of time"), he is nonetheless an instructor in his local union and, since 2008, first president, then vice-president, of his tribunal. He has a quite unusual view of the Labor Code: "when you read those twisted articles - they're really twisted - you start the first sentence and the last sentence tells you that what came first was the same thing. .. that's the Labor Code. Or else it sends you on to another article that sends you on to a third article. . . so you have to go through four articles to understand what you've been reading". He is also totally opposed to using jurisprudence — considering it too changeable - to evaluate an issue and make a decision and prefers in that case to stick to the Code. (Interview 3 May 2005).

Nevertheless, not all the councillors share the same conception of their role and the relation to the law that goes with it, far from it: the two FCAs reveal a sort of "soft belly" of the prud'homme tribunals, made of individuals who occupy no particularly distinctive position, have no training and no legal function in their own organization. Analyzing the profiles of the individuals who never filled any particular position in a prud'homme tribunal shows that this often concerns employers, but also women ${ }^{13}$, members of "miscellaneous activities" sections, executives and members of the higher intellectual professions and lastly, employees of very small firms.

All in all, personal involvement in the prud'hommes, like the law they produce, covers a great diversity in the forms of commitment, in the ways of "holding" one's place, i.e. in the last analysis, in the ways of judging and producing labor law. When all is said and done, three groups stand out: in the first place, "prud'homme professionals" — generally members of the employee college who defend a law officially based on practice and try to combine trade-union demands with legal requirements; next, directors of SMEs, whose conception of labor law is less caught up in the constraints of the law and more based on the personal regulation of labor relations; and lastly, executives - wage-earners as well as employers, frequently versed in social law and defending a more academic conception of labor law. If, in spite of everything, these various conceptions are able to coexist and allow justice to be rendered, it is precisely because the prud'hommes produce a mixed sort of law, both respectful of legal norms and loyal to their trade-union affiliations.

\footnotetext{
13 Over $60 \%$ of women councillors never held any distinctive position in the prud'homme tribunal and proportionally speaking they are largely in the minority as section presidents or in the interim decisions section.
} 


\section{The production of French labor law}

By the decisions they render on questions concerning individual litigations in labor relations, particularly in affairs of redundancy, prud'homme councillors fabricate part of France's labor law. Though legal texts harp on the fact that prud'homme tribunals in general are a "legal fiction", we have seen that only a fraction of the councillors - those who are most active in their trade-unions and most personally involved in prud'homme activities at the same time - actually have a hand in creating it. We must now examine to what extent that law is also produced by the institution itself - and if the nature of the institution, i.e. the ways individuals are involved there, the practices it generates and on which it is founded - affect the type of law produced. It means showing, for instance — in response to the challenge contained in Bruno Latour's work (Latour, 2004) that the law is first of all the product of those who make it and of the institutions that shelter it. But, before tackling the specific moments when opinions are explicitly generated - hearings, deliberations, drafting decisions - which allow one to actually see the councillors in the act of producing prud'homme law, we must first study the institutional and organizational systems that structure their activity and enable a certain number of councillors to fit into their role.

\subsection{Learning a double role}

Sitting on a prud'homme court is a role one learns through attendance, decision-making experience and participation in a whole set of interactions. As Jacques Lagroye has written, sociology must "ponder the way that filling a role modifies one's conception of it and therefore, somehow, one's position when in that role" (Lagroye, 1997). As in any other institution, participating in a prud'homme tribunal is a socializing experience (Georgakakis, 2010), but in a very special way, for it allows councillors to acknowledge the double bind in which they find themselves: judging as jurists, and belonging to a trade-union at the same time. It is thus necessary to examine, as Christian Bessy did when studying the organization of lawyers' work, the institution's impact on prud'homme councillors' judiciary and legal “inventiveness” (Bessy, 2010).

\subsubsection{Union and legal injunctions}

Playing the part of a prud'homme depends above all on being able to assimilate a set of often contradictory public declarations and decisions concerning the definition of prud'homme justice. Not judicial enough for some, not militant enough for others, councillors are constantly reminded of their multiple memberships and the complexity of their role. Part of the criticism emanates from those responsible for the legal sector of the trade-union confederations and the national employer associations. To them, prud'homme councillors are potentially uncontrolable, because as elected officials, they are led to judge not only in the name of their organizations but in the name of the French people; and also because the law is always a powerful instrument for freeing representatives from a strict obedience to their organizations (Willemez, 2006). The latter are wary of the "deviation" that might come as a result of the temptation to "go it alone" and act like a "free agent", as the following interview with a councillor in charge of the legal department of a union confederation makes clear:

"It is true that there are sometimes deviations among activists who only concentrate on individualistic prud'homme defence that is like a carbon copy of a lawyer's office, that's not at all the way it should be. The legal dimension has to be taken into consideration... we don't exist in a vacuum, we're a union organization." (Interview 7 June 2006) 
Referring to the fact that the prud'homme tribunal is only one of the places available for dealing with conflict in labor relations (Pélisse, 2007, 2009), all the persons in charge of a legal department we interviewed, whether member of a trade-union or an employer association, mentioned their efforts to control councillors and make them reflect upon the tactical and strategic applications of the law. Such injunctions are omnipresent in the legal literature published by the trade-unions as well as in prud'homme training sessions, and councillors present themselves first and foremost as accomplished union activists. By the questions they put during hearings, but also during deliberations, through various signs, words, alliances. . . they demonstrate their allegiance to their college or a union.

However, councillors most often have the finger pointed at them for opposite reasons by the law professionals they happen to encounter. Allegedly too close to their organizations, or because they are not really professional magistrates, they are supposedly incapable of administering justice according to the established standards of judiciary excellence. That sort of criticism is voiced not only in the Department of Justice but even in the prud'homme tribunals by lawyers as well as court clerks who often dwell on councillors' lay character: their verdicts are said to reflect their legal "incompetence" — uncertainty concerning a procedure, a problem concerning legal argumentation or errors in the drafts, even spelling or grammar mistakes in their written opinions are pointed out. Such legal or pedantic judgments constantly remind councillors they need to keep their union memberships at arm's length, the only way to make their decisions legitimate by making them neutral. The metaphor of "changing hats" or "labels" when entering the courtroom for a hearing or a deliberation is often used to communicate that sort of intellectual gymnastics.

“The fact we've been elected means we're there to judge, we put our labels by, don't we... that doesn't mean we forget who we are, do we, it's normal, we have our feelings but we put our labels by. We're not there to... [...] There was a councillor-employee who said: "well yes, but we belong to the same union so you're going to help me"... but that's not the way to go." (Employer, retired engineer and former executive officer and president of a textile industry, interview February 9, 2006)

The "hat" or the "label" are doubly meaningful, they represent both the college and the union. "Putting one's label by" means rejecting the allegiance and proximity to the trade-union that could warp their impartiality and jeopardize the legitimate nature of their verdicts.

Yet the double bind that researchers often emphasize as a factor that throws them into a quandary (Hunout, 1987), is precisely what constitutes councillors' originality and specificity. Their role finds its expression in an original form of labor law, backed both by legal guarantees and a union membership that vouches for their in-depth knowledge of the "field".

\subsubsection{Institutional systems}

That dual logic of action and judgment is reinforced by an ensemble of organizational and institutional systems that strongly impact the image actors have of themselves as prud'homme councillors.

In every jurisdiction, and particularly in a French labor tribunal, judges' work is organized by "turns": the president and vice-president of the tribunal - or even, in the case of larger courts, of a section - regularly organize hearings, summoning the councillors according to their availability, and having each one in turn sit in the president's chair. While trying to respect individual schedules, they also try as far as possible to achieve equality in the amounts of time and effort put in and to bring together in the courtroom both experienced councillors and newcomers. The considerable amount of time spent in the institution also allows them to guarantee the longevity 
of the jurisdiction beyond individual withdrawals, by replacing the councillor gone missing. With the help of the court clerks, with whom they closely collaborate or even sometimes develop a form of complicity, they are the pillars of the institution.

Observation notes taken during an interview with an employee councillor, vice-president of a section, in a large city:

Before starting the interview, Didier J. tells me we are often going to be interrupted because several councillors have cancelled for the afternoon's hearing and he is on the lookout for substitutes. During the interview, his phone rings several times (in particular one long conversation with the employer president of the section). He explains how hard it is to find substitutes and the fact that he himself often stands in for another councillor. It must be said that he is very often on hand, a fact I understand later when I see his status on the list provided by the Labor Department: he is unemployed. (Excerpt from field notes, 3 May 2006)

The part played by "prud'homme professionals" so regularly in attendance in the Labor Tribunal is not limited to ensuring "turns". They are also a sort of fixed point guaranteeing the stability of the institution, producing and maintaining sociability within the tribunals. Omnipresent in the library (when there is one), in their offices, even at the coffee machine or among the public during exceptional hearings, they are the hub of informal exchanges. It is therefore possible to partially assimilate the conseil de prud'homme to a "collegial phenomenon", like the professional groups, attorneys or judges in the business tribunals studied by Emmanuel Lazega (Lazega, 2001, 2007).

Prud'homme life is also marked by ceremonies and rituals that create or revive feelings of belonging to the judiciary, though in a very specific manner. Though prud'homme councillors do not wear the robe, they wear a medal around their neck. It symbolizes the fact they sit in judgment in the name of the French people and gives them the symbolic strength to force the respect of those usually considered above them, such as — as far as employee councillors are concerned — lawyers or employers in particular. Also, during the hearings, many "interaction rituals" among councillors allow players to be "reciprocally accredited", to co-produce "the expressive order currently in force" (Goffman, 1974, p. 33, 36): smiles are exchanged, looks encompassing the public, deliberate expressions of unconcern, etc. The most important ceremony remains nevertheless the first hearing of the year that brings together in the great hall of each tribunal, around the president and vicepresident of the Council, all the councillors and court clerks, lawyers and magistrates, locally elected public officials, and civil servants from regional administrations, under the benevolent but watchful eye of the public prosecutor in full garb. Playing in this case the part of "institution ritual" (Bourdieu, 1982), the first hearing consecrates the difference between the professional magistrate (in this case the qualified judges and chief court clerk, all in full dress) and lay judges (prud'homme councillors), while at the same time reminding the latter how priviledged they are to be included in the judiciary, and the potential or real social capital that is theirs thanks to their commitment to the institution.

Report on the observation of the solemn opening session of a Prud'homme Council in a middle-sized city of Western France:

Invited by the new President of the Council, I get there on time: the courtroom is packed, nearly forty people. The public is aged on the average between 50 and 60, women are in the minority and there are a few young men in their thirties. Almost all the men are in jackets and ties, the women wear suits. Male and female councillors exchange pecks on the cheek or handshakes and chat agreeably. Some of them seem not to have seen each other for a long 
time, others allude to the cases they are going to have to deal with together. The first row is occupied by the invited VIPs: the two Deputies, the Mayor, one of the vice-presidents of the General Council, the president of the business tribunal, the president of the Bar Association and Madame la Présidente of the Civil Court (Tribunal de Grande Instance, TGI).

The bell rings and all the players enter: the prosecutor in his robe decorated by two medals and girded by a crimson belt, followed by the outgoing vice-president and president, and lastly the chief records clerk and her colleague, both also in full regalia. The outgoing president reads the report of the past year in a very monotonous voice: he insists on the low rate of reversals in appeals and the small number of opinions sent up for arbitration. He recalls the ongoing discussion with the Order of Advocates of the Poitiers Bar concerning an agreement to reduce the number of referrals. In the end he mentions the Prud'homme Council's participation in the "Days of Justice" (Journées de la justice), particularly in the round-table on economic and social law that assembled consular justice, the labor tribunal and the business world. He then asks the prosecutor for his requisition. In a very congratulatory tone, the prosecutor recalls the history of the prud'hommes and its very general usefulness, praising more specifically the efficiency of this particular Council. But at the end of his eulogy, he confuses the president and vice-president who have the same first name!

The ceremony becomes more solemn when the head clerk reads the minutes of the General Assembly before the new president and new section presidents and vice-presidents are voted in, and the interim relief jurisdiction (référés) is formed. Then the vice-president and president rise and change places. F.P. is the new president of the French Conseil de prud'hommes in Poitiers. The photographers of the two local papers immortalize the event. Visibly moved, F.P. takes the floor and gives a well-written speech, full of far-fetched and somewhat old-fashioned rhetoric (repetitions, using the verb savoir in the sense of connaître....). (Field-notes, 11 January 2007)

As François Héran suggests, all this implies that though rituals do not necessarily breed belief, they lead to producing and reproducing an institution, at least by reminding actors of the interests and purposes that motivated their involvement in the first place (Héran, 1986). As a ceremony intended to re-enchant prud'homme activity, the opening session is also a way of reminding everyone of their role and of concretely redefining councillor's positions — albeit subordinate as judges.

\subsubsection{Of informal training and apprenticeship}

Though all these systems are how one learns to be a prud'homme and the type of law the institution must produce, that type of law also depends on a full set of formal or informal acquisitions, on both judiciary and trade-union knowledge and know-how.

Legislation provides for the instruction of prud'homme councillors ${ }^{14}$. According to our questionnaire, most of the councillors, employers included, had received some form of training $(86.3 \%$ of employees and $76.5 \%$ of employers). Training periods were relatively short and usually simply an initiation to labor law and procedure, whether through role-playing, lectures by academics or lawyers, or actual, practical applications of social law (Brugnot and Porte, 2010). Such training

\footnotetext{
14 The law of 1979 reorganized the prud'homme councils and provided for five weeks of training per councillor over the six years of their electoral mandate. Financed by the State, it is contracted out by training associations to trade-union and employer organizations.
} 
is not merely meant to learn about the law, however; it aims to spread the conception of law and justice defended and promoted by their organizations. As in all union training programs (Ethuin and Yon, 2011), what is being transmitted and acquired by the councillors is thus knowledge of the law, but of a law that fits in with their own "organizational culture" (Eliasoph and Lichterman, 2003), i.e. a specific application of procedural tools, a preference for certain legal categories rather than others, etc.

Beyond that form of training, it is by living the daily life of a prud'homme that councillors' knowledge and know-how are most conclusively constructed and intertwined. Through a process of observation and imitation during hearings, under the auspices of "eminent forebears", as well as in the time spent writing up opinions in collaboration, legal and union categories of judgment are disseminated, as well as how to be a "good" prud'homme, i.e. learning how to judge without having one's decision reversed later while still representing one's college or union. The following excerpt from an interview with a female councillor clearly illustrates the combination between formal training and learning on the job, but also reminds us of the importance of people's previous dispositions before entering the French Conseil de prud'hommes, as concerns professional activity, in her case (but also family life):

"I wanted to live up to the challenge, because I was becoming a judge, but non-professional. And I thought to myself, what with my experience — in a company both as CEO and as staff representative, which isn't very common either. . Also, my taste for labor law... because for years I've been living with the Code du travail under my left arm, or my right, as you like... So I thought to myself that by continuing to work and to learn, there was no reason not to succeed as well as a professional judge. Because in a few years, thanks to experience and reading, and learning, I had the capacity to become as competent as a professional judge.

-So you weren't surprised, or scared?

-No, for one thing because I went into it knowing exactly what I was doing, and I had made up my mind to spend as much time on it as necessary to make good [...] The CGC [executives' trade-union] organized training periods for newly elected councillors so I went. Besides, we were allowed to advance step by step. For the first nine months, we were not allowed to preside a hearing, and after that it was on a volunteer basis, when one felt ready. And for those who didn't feel right doing it, they were allowed to work by twos: officially they presided the hearing but a councillor from the same union was present in the courtroom to help write it up [...] And then, too, during the hearings, during the deliberations, I don't hesitate; when I don't understand something in an argument, I say so. In that way I get the benefit of the experience and knowledge of seasoned councillors like M. D. If my memory serves me right, M. D. is a former DHR [in a very large firm], retired, who's been doing labor law for years... And for me it's a pleasure to be in a deliberation with older, more seasoned judges.

-And that's how you learn?

-Yes, not only, but yes. And now I can call on my own personal jurist (she turns to her son, a student in a Master 1 program in law)."

As in all processes of acquisition, formal training and learning on the job are more efficient when done by individuals already involved in an institution and by those with a certain number of dispositions, not only for law but also for union-work, who are thus liable to benefit more from them. They are the ones who keep the Council on its toes and are the main producers of the specific labor law known as prud'homme law. 


\subsection{Tangibly producing labor law}

What councillors actually do might be described in "praxeological" perspective (Dupret, 2010). As in all judicial activity, it means placing a litigation squarely in front of the legal categories of the Labor Code or in publications on jurisprudence. In other words, like statisticians, a councillor's task is, by interpreting legal texts, to "code unique cases" (Desrosières, 1993), which here concern working conditions: redundancies, difficulties with the hierarchy and discipline, number of hours worked, defining the job. . . But in order to do it, they owe it to themselves to first understand what actually took place, by studying the testimony in the files, asking questions during the hearings and listening to the pleas of the lawyers or union defenders. Then comes the moment of the collegial discussion, known as the deliberation, during which the opinion is formed. Finally, the president — assisted or not by a councillor — writes up the decision. The text sums up the affair and the arguments on both sides and then motivates the decision.

This description is important to be able to measure the reality of judicial work; yet it leaves aside the social structures that constrain prud'homme councillors and make the law they produce original.

\subsubsection{Structural constraints and judicial practices}

First of all, and contrary to what takes place in a penal jurisdiction ${ }^{15}$, the procedure is above all oral. A good part of the legal work is accomplished during the hearings, by listening to the pleas, through the questions put to the different parties and through note-taking. Though lawyers generally submit written conclusions and the files contain all the pieces permitting councillors to form an opinion, it is mainly the hearing that allows them to arbiter between the arguments and make up their minds. The notes taken during a hearing therefore play a major role. Observation and interviews show us what was jotted down and what was ignored.

Observation notes taken down during a main hearing:

During the hearing, while the president asks a great number of questions, the other councillors rarely intervene. Councillors take notes but apparently at random: they pick up their pens when the lawyers tell the plaintiff's life story, give elements of his/her personality or mention interpersonal relations in the firm; the same is true when the case is complex, as was the last one we witnessed (which had to do with accounting). They never take notes when lawyers refer to jurisprudence, a disposition of the Labor Code or a collective agreement. On the other hand, they take careful note of lawyers' questions and of the facts: salaries and bonuses, dates of events or the precise title or position occupied by the employee. (Field notes, observation, 23 November 2005)

Interviewing the councillors confirmed that taking notes is especially linked to what the parties ask and the facts as they are exposed. The jurisprudence quoted by the lawyers is not usually considered interesting, to the point that during deliberations, the Labor Code alone is used to qualify the facts. Also, councillors often mention the fact the parties need to be present to have the possibility to ask them questions. Lawyers are often seen to be acting as obstacles between the world of work and the Council, which an idealized version sees as a jurisdiction supposed to repair from the inside whatever goes wrong between employees and employers (Cam, 1981).

\footnotetext{
15 Oral procedure is legal in civil affairs, notably in the Civil Courts (Tribunal d'Instance or Tribunal de Grande Instance) in certain cases (especially when the parties are not obliged to be represented by a lawyer) and in social jurisdictions (rent and lease tribunals, social security tribunals and Conseils de prud'hommes).
} 
Secondly, all prud'homme councillors are not on an equal footing with respect to the scriptural and lectoral competences required to carry off their judicial activities day by day. Many councillors willingly describe their difficulties when faced with the Labor Code or the way they relate to the stuff labor law is made of, and don't hesitate mentioning the efforts they must make when drafting an opinion:

"Q.: What about writing, do you write up the opinion?

-I love writing [...] I write it up all by myself. When I began writing, they explained a little how it should be done, the facts, the means, the parties and all that. . . So I did it all alone and I went to look up other factual accounts, for inspiration; it took me some time - the first one took me six hours! Then I gave it to M.P., the chief registrar and he said: "it's very good". So I was really pleased. Later on, I drafted with friends, other friends, it was their first mandate, it was even harder for them." (Retired RR worker (SNCF), CAP [primary level vocational diploma], elected in 1995. Interview 9 June 2006).

Their difficulties are often compounded by a strong sense of being illegitimate, a feeling exacerbated by the way many legal professionals (clerks, lawyers, arbitrating judges...) look down on them. Councillors are thrown back on their illegitimacy regarding their legal status and on the supposed lesser value of their judicial decisions. At the same time, confronted by such value judgments - including favorable ones, as was the professor-like opinion of the chief registrar in the preceding interview - many councillors fuss over form and become hypercorrect about legal matters. Their preoccupation with form is all the more acute as they are particularly anxious their decisions might be reversed in the court of appeals. It is certainly in their interest to assimilate the rationale proper to the legal domain, but they do so with anxiety, and their life in the prud'homme council is one of permanent legal and "linguistic insecurity" (Labov, 1976).

But the main variable which must be accounted for when analyzing the specific nature of prud'homme law is the fact that councillors also judge as members of a trade-union. Their ways of asking questions, of speaking up during deliberations, the circumstantial alliances between organizations. . . all these elements make the prud'hommes a particularly political sort of law, in the sense that decisions reflect the power struggles and oppositions between different world views. Belonging to the employee or the employer college - which we saw earlier is a particularly structuring feature of the institution as a whole - is most obviously manifest during deliberations. Strategies for taking the floor and attempts at changing the terms of the exchange turn these moments into plays for power and negotiations that strongly remind us of employee-employer exchanges in a firm.

The best example of this is doubtless Roger $\mathrm{H}$, employer, president of the management section of a large tribunal. Interviewed after the hearing, he is already looking ahead to the deliberation scheduled to take place a few days later which will force him to prove his talents as negotiator:

"Q.: Did you come to an agreement with the other employer ahead of time?

-No, we don't discuss it. But we do it during the deliberation; during the deliberation, the messages get through. And I know full well that the employer councillors expect me to talk first [...] But we have to let the employees talk first [...] OK, what can an employer president do? He'll say: 'OK, such and such a file... gentlemen, what do you think? And from time to time, you put in: 'we don't usually say that, but this is our position today [...]' there's a whole technique, in fact." 
He then insists on the need to begin by such or such an aspect rather than another, while the other college would do the reverse: "employees are going to start where they're sure to get money back." (Interview of 28 April 2006)

Given such conditions, the law created by prud'homme councillors is in fact the expression of a power struggle, the result of a tug of war between representatives of colleges and/or trade-union organizations. But it is encased in a legally acceptable form that refers to legal categories as much as to practical ones.

\subsubsection{Between the didactics of law and explicitating the practical meaning of work}

Witness to those specific properties, the language of prud'homme law is marked by a twofold concern: accessibility and representing the working world.

Prud'homme councillors worry first of all about being pedagogically efficient during their activity as judges, guiding the parties through the procedure, explaining the decisions in an accessible language as devoid as possible of legal "jargon". Councillors claim it is one of their missions to make labor law accessible, even to acculturate people not very gifted in legal matters to the norms of the Labor Code. It is just as true for employers, who are often helpless when it comes to defending company directors guilty of ignoring the most elementary rules of redundancy, as it is for employees who must be made to understand that it is not revenge they are after but having their rights recognized.

During her interview, Françoise N., for instance, an elected CFDT councillor in a large tribunal, boasting a law degree and employed in an auditing company, described at length the pedagogical aspect of her activity both at the prud'homme council and when manning the office in the legal department of her union: "I find that with regard to employees who arrive totally helpless and alone, we're really useful [. . . ] they're lost, poor things, they come as amateurs, or else victims. . . more or less of harassment." From the outset, she mentions the difficulty in accessing the prud'hommes: "I think that maybe one employee out of five or ten dares [insists on the word] take their case to the prud'hommes, because seen from the outside, as soon as it's a problem of justice, they think: 'olala, it must be complicated, you need money to pay an attorney, etc."” (Interview $1^{\text {st }}$ June 2006)

At the same time, realistic descriptions of the work or of social relations in the firms abound in the hearings and minutes of prud'homme decisions. Belonging to a trade and a specific occupation prompts councillors to delve into the technical aspects of the professional activity at the heart of the litigation and to describe the contents of the job at length. Most often, the opinions, which are fairly long, explain the facts very precisely, quote the e-mails in dispute and the letters announcing the dismissal, giving the reader the impression they are witnessing the inner workings of the daily routines of interpersonal relations in a company.

It is naturally impossible to quote judgments in extenso, for they are always very long; we can however describe the one drafted about M. H., a salesman in a publishing firm who was fired for lack of results.

The judgment quotes the part of the work contract concerning remuneration, enumerates very precisely the salaries received, M. H.'s objectives and sales results, quotes the correspondence sent by his superiors with advice to improve his performance, then the warning letters and his answers, and finally the official letter of dismissal. In the end, the judgment indicates that the dismissal had no real or serious motive, declaring that "although M.H.'s results have been insufficient, given the results of the group as a whole, they are in an 
upward phase. A sanction may be justified but they are certainly not sufficient cause to justify a dismissal." (Judgment April 2004, management section of a prud'hommes tribunal in a large city) ${ }^{16}$.

The fact the reality of the job is so tangibly present has a double effect. On the one hand, it allows councillors to imagine more accurately what actually transpired during the conflict, and thus to approach a form of judicial truth (Rudde-Antoine, 2007). On the other hand, it allows them to claim a new form of legitimacy, connected to their first-hand knowledge of the world of work. While union delegates sometimes seem far removed from the workplace they are supposed to represent, the image of a prud'homme councillor is one of an accomplished representative, able to turn law, the trial and its consequences into a privileged stage upon which labor relations can be authentically played out.

Thus, Weber's categories of material law and formal law (Weber, 2007 [1913]) often presented as alternatives, in prud'homme judgments work as one. A law on power struggles that conveys the reality of work but also a law in conformity with the norms of "good justice": those are the properties, different or even conflicting, that together are contained in prud'homme law. It therefore becomes particularly interesting to observe how that law is subsequently "purified" and transformed by the other actors in the judicial arena so as to change it into general law. Decisions published in law journals, new procedures in the appellate court or court of cassation, and in the end generalization through doctrinal articles or academic teaching make that law less unique, extricate it from the "cloaca" of power games and local, socio-economic conjurations that produced it in the first place. It is all these processes that in the end become known as "Labor Law".

\section{Conclusion}

Studying the way labor law is made by seeing how prud'homme councillors produce it therefore requires examining the object from three different points of view. The first logic, which is sociographic, permits studying the judges, who they are, what social groups they belong to, how they entered the jurisdiction. That allows us to grasp both the importance of the collegial factor that, more than all the other variables, structures the institution, and the importance of the experience acquired there. A second logic, institutional and organizational, leads one to underscore the systems that allow councillors to incorporate their role as prud'homme judges and strike a balance between the fact they belong to a trade-union and the need to access the legal system. A third logic, that might be termed "socio-cognitive", requires concentrating on the actual, concrete production of opinions, which appears to be a combination of three activities: acting as union representative, meeting the challenge of judicial norms, representing the world of work.

Are these results valid exclusively for labor law and prud'homme councillors? Considering prud'homme councils as an ideal-typical combination of formal and material rationality, could such a method not conceivably be beneficial when studying all ways of judging? Though certain scholars have analyzed the French judiciary concretely, we lack the research that, as a British school of legal sociology suggests, would analyze the reality of magistrates' artisanal approach,

\footnotetext{
16 This judgment is excerpted from a body of texts used in a research project conducted within the framework of a convention with the UCI-FO trade-union (Ricciardi et al., 2008).
} 

know-how and craftsmanship ${ }^{17}$. That is conceivably what the object of a sociology of the law and
the judiciary could be.

\section{Disclosure of interest}

\section{The authors have not supplied their declaration of conflict of interest.}

\section{References}

Bessy, C., 2007. La contractualisation de la relation de travail. LGDJ, Paris.

Bessy, C., 2010. Les enjeux de la qualité: innovations juridiques et diversité des exercices professionnels. In: Favereau, O. (Ed.), Les avocats, entre ordre professionnel et ordre marchand. Lextenso, Paris, pp. 83-110.

Bourdieu, P., 1980. Le sens pratique. Editions de Minuit, Paris.

Bourdieu, P., 1982. Les rites comme actes d'institution. Actes de la recherche en sciences sociales 43, 48-53.

Brugnot, T., Porte, E., 2010. La formation prud'homale à la CGT, entre autonomie et instrumentalisation: expérimentations pédagogiques et enjeux organisationnels. Colloque syndicalisation et formation. Université Lille 2.

Cam, P., 1981. Les Prud'hommes, juges ou arbitres? Les fonctions sociales de la justice du travail. Presses de la Fondation nationale des sciences politiques, Paris.

Desrosières, A., 1993. La politique des grands nombres. La Découverte, Paris.

Dufour, C., Hege, A., 2002. La place des femmes dans les conseils de prud'hommes. In: Report of the IRES, Noisy-leGrand.

Dupret, B., 2010. Droit et sciences sociales. Pour une respécification praxéologique. Droit et Société 75, 315-335.

Eliasoph, N., Lichterman, P., 2003. Culture in interaction. American Journal of Sociology 108, 735-794.

Ethuin, N., Yon, K., 2011. Les mutations de l'éducation syndicale: de l'établissement des frontières aux mises en dispositif. Le mouvement social 235, 3-21.

Fielding, N.G., 2011. Judges and Their Work. Social \& Legal Studies 20 (1), 97-115.

Georgakakis, D., 2010. Comment les institutions (européennes) socialisent. Quelques hypothèses sur les fondements sociaux de la fabrique des euro-fonctionnaires. In: Michel, H., Robert, C. (Eds.), La fabrique des Européens. Processus de socialisation et construction européenne. Presses universitaires de Strasbourg, Strasbourg.

Goffman, E., 1974. Les rites d'interaction. Minuit, Paris.

Guillaume, C., Pochic, S., 2009. La professionnalisation de l'activité syndicale: talon d'Achille de la politique de syndicalisation à la CFDT? Politix 85, 31-56.

Héran, F., 1986. Le rite et la croyance. Revue française de sociologie 27 (2), 231-263.

Hunout, P., 1987. Conseil de prud'hommes: un exemple de prise de décision dans un contexte institutionnel. Revue française de sociologie 28 (3), 453-481.

Kritzer, H.M., 2007. Toward a Theorization of Craft. Social \& Legal Studies 16 (3), 321-340.

Labov, W., [Chapitre 5] 1976. L'hypercorrection de la petite bourgeoisie comme facteur de changement linguistique. In: Sociolinguistique. Editions de Minuit, Paris, pp. 189-211.

Lagroye, J., 1997. On ne subit pas son rôle. Politix 38, 7-17.

Latour, B., 2004. La fabrique du droit. La Découverte, Paris.

Lazega, E., 2001. The Collegial Phenomenon: the Social Mechanisms of Cooperation among Peers in a Corporate Law Partnership. Oxford University Press, Oxford.

Lazega, E., 2007. Quête de statut social, partage des compétences et néo-corporatisme au Tribunal de Commerce de Paris. In: Michel, H., Willemez, L. (Eds.), La justice au risque du profane. Puf/CURAPP, Paris, pp. 87-104.

Lazega, E., 2009. Quatre siècles-et-demi de New (New) Law \& Economics: du pragmatisme juridique dans le régime consulaire de contrôle social du marché. Revue française de socio-économie 1 (3), 97-120.

Mauger, G., 2006. L'accès à la vie d'artiste: sélection et consécration artistiques. Éditions du Croquant, Bellecombe-enBauges.

Michel, H., 2008. L'expérience professionnelle des conseillers prud'hommes, usages et enjeux d'une compétence de terrain. In: Michel, H., Willemez, L. (Eds.), La justice au risque du profane. Puf/CURAPP, Paris.

\footnotetext{
17 See a 2007 issue of Social and Legal Studies entitled “Judgecraft: an Introduction" (Moorhead and Cowan, 2007). See also Kritzer, 2007; Fielding, 2011.
} 
Michel, H., Willemez, L., 2007. Les conseils de prud'hommes entre défense syndicale et action publique. Actualité d'une institution bicentenaire. In: Report for the Research Program «droit et justice», Paris.

Moorhead, R., Cowan, D., 2007. Judgecraft: an introduction. Social \& Legal Studies 16 (3), 315-320.

Offerlé, M., 2009. Sociologie des organisations patronales. La Découverte, Paris.

Pélisse, J., 2007. Les usages syndicaux du droit et de la justice. In: Commaille, J., Kaluszynsky, M. (Eds.), Les fonctions politiques de la justice. La Découverte, Paris, pp. 166-189.

Pélisse, J., 2009. Judiciarisation ou juridicisation? Usages et réappropriations du droit dans les conflits du travail. Politix $86,73-96$.

Ricciardi, F., Verrier, B., Willemez, L., 2008. Les cadres et la justice du travail, Le contentieux prud'homal chez les cadres, révélateur d'une relation d'emploi sous tension? In: Research report for the UCI-FO and IRES, Noisy-le-Grand.

Rudde-Antoine, E., 2007. Le procès. PUF, Paris.

Weber, M., 2007. [1913]. Sociologie du droit. PUF, Paris.

Willemez, L., 2003. Quand les syndicats se saisissent du droit. Invention et redéfinition d'un rôle. Sociétés contemporaines $52,17-38$

Willemez, L., 2006. Le droit du travail en danger. Éditions du Croquant, Bellecombe-en-Bauge.

Zarca, B., 1986. L'artisanat: du métier traditionnel au groupe social. Economica, Paris. 